\title{
A new Eocene genus of the subtribe Tylodina (Coleoptera: Curculionidae) and notes concerning local differences of Baltic amber in the Kaliningrad Region
}

\author{
Andris Bukejs ${ }^{1}$, Vitalii I. Alekseev ${ }^{2,3}$, and Andrei A. Legalov ${ }^{4,5}$ \\ ${ }^{1}$ Institute of Life Sciences and Technologies, Daugavpils University, Vienības 13, Daugavpils, 5401, Latvia \\ ${ }^{2}$ Shirshov Institute of Oceanology, Russian Academy of Sciences, Nahimovskiy prospekt 36, 117997 Moscow, Russia \\ ${ }^{3}$ Kaliningrad Regional Amber Museum, Marshal Vasilevskii square 1, Kaliningrad, 236016, Russia \\ ${ }^{4}$ Institute of Systematics and Ecology of Animals, Siberian Branch, Russian Academy of Sciences, \\ Frunze Street 11, Novosibirsk, 630091, Russia \\ ${ }^{5}$ Altai State University, Lenina 61, Barnaul, 656049, Russia
}

Correspondence: Andrei A. Legalov (fossilweevils@gmail.com)

Received: 25 February 2020 - Revised: 19 March 2020 - Accepted: 25 March 2020 - Published: 17 April 2020

\begin{abstract}
Based on a well-preserved specimen from Eocene Baltic amber, a new weevil - Baltacalles triumurbium gen. et sp. nov. - is described and illustrated. The new fossil genus is similar to the extant Acalles Schoenherr, 1825 but differs from it in the denticulate femora, abdominal ventrites 1-2 combined about 2.8 times as long as ventrites 3-4 combined, distinct scutellum, narrow, subparallel metepisternum, not flattened rostrum, and narrow forehead. This is the first described representative of the Tylodina (Molytinae: Cryptorhynchini) described from Baltic amber. The data on the geographically and stratigraphically distinct local sources of Baltic amber in the Kaliningrad Region are provided; the main sampling localities are listed and photographed. The importance of the possible exact labeling of the material is emphasized.
\end{abstract}

\section{Introduction}

Weevils from Eocene Baltic amber are very diverse. The family Curculionidae is represented by subfamilies Erirhininae, Molytinae, Lixinae, Dryophthorinae, Cossoninae, Conoderinae, Curculioninae and Entiminae. Fifty-five weevil species have been described from this deposit (Legalov, 2020). New species are found in new amber materials. The descriptions of these species and the establishment of their systematic positions allow us to add new data to the knowledge of the structure and relationships of the Eocene faunas. This also enables the identification of phylogenetic relationships between extinct and extant taxa.

In the new amber material, a new species and a new genus of the subtribe Tylodina belonging to the tribe Cryptorhynchini and the subfamily Molytinae was discovered. This is the first described representative of Tylodina from Baltic amber.

\section{Material and methods}

The material examined is deposited in the Museum of Amber Inclusions, University of Gdańsk (Poland) (MAIG). The amber piece was polished by hand, allowing improved views of the included specimen, and was not subjected to any supplemental fixation.

Observations of this specimen were made using a Nikon $\mathrm{SMZ}^{\circledR} 745 \mathrm{~T}$ stereomicroscope. The photographs were taken using a Canon $70 \mathrm{D}^{\circledR}$ camera with a macro lens (Canon MPE$65 \mathrm{~mm}$ ). Extended depth of field at high magnifications was achieved by combining multiple images from a range of focal planes using Helicon Focus ${ }^{\circledR}$ v. 6.0.18 software. Measurements were taken using an ocular micrometer (expressed in millimeters).

The morphological terminology used in this paper follows Lawrence et al. (2010). 


\section{Systematic paleontology}

Family Curculionidae Latreille, 1802

Subfamily Molytinae Schoenherr, 1823

Tribe Cryptorhynchini Schoenherr, 1825

Subtribe Tylodina Lacordaire, 1865

Genus Baltacalles gen. nov.

urn:Isid:zoobank.org:act:71577B46-1637-478B-A06962C592AE4E15

\section{Type species}

Baltacalles triumurbium sp. nov., herein designated.

\section{Etymology}

The name is formed from the Latin balticum (Baltic) and the generic name "Acalles". Gender masculine.

\section{Description}

Rostrum curved, not flattened, not separated by transverse groove; antennae geniculate, inserted near middle of rostrum; funicle 7-segmented; scape shorter than funicle and not reaching eye; forehead narrow; eyes well developed, large; scutellum distinct; elytral humeri reduced; prosternum with rostral channel margined by carinae; apex of rostral channel reaching mesoventrite, margined by carina; postcoxal portion of prosternum not bounded by carinae; mesepimeron not enlarged and invisible between bases of prosternum and elytra; metaventrite shorter than abdominal ventrite 3; metepisternum narrow, subparallel; abdominal ventrites $1-5$ oriented in one plane; ventrites $1-2$ elongate, fused, about $2.8 \times$ as long as ventrites 3-4 combined; suture between ventrites 12 shallow, not straight; abdominal process as broad as metacoxa; posterior margins of ventrites 2 and 3 straight; tibiae with large uncus and two groups of setae; femora denticulate; protibiae distally without mouth groove and row of dense erect setae (grooming device); mesotibiae without denticle in middle of exterior margin; tarsomere 5 with free claws not separated by dermal lobes.

\section{Differential diagnosis}

The new fossil genus is similar to the extant Acalles Schoenherr, 1825 but differs from it in the denticulate femora; abdominal ventrites $1-2$ combined about $2.8 \times$ as long as ventrites 3-4 combined; distinct scutellum; narrow, subparallel metepisternum; not flattened rostrum; and narrow forehead.

\section{Remarks}

The geniculate antennae, elongate and fused ventrites 1-2, and ventrites $1-5$ oriented in one plane suggest placement of
Baltacalles gen. nov. in the family Curculionidae. The tibiae with large uncus and two groups of setae, straight posterior margins of ventrites $2-3$, protibiae distally without mouth groove and row of dense erect setae (grooming device), tarsomere 5 with claws not separated by dermal lobes, antennae inserted near middle of the rostrum, and mesepimeron not enlarged and invisible between bases of prosternum and elytra, suggest placement in the subfamily Molytinae. Placement of this new fossil genus in the tribe Cryptorhynchini is based on the prosternum with rostral channel reaching middle coxae and margined by carinae, its apex reaching mesoventrite and margined by a carina, postcoxal portion of the prosternum not bounded by carinae, eyes well developed, rostrum not separated by groove, mesotibiae without denticle in middle of exterior margin, scape shorter than funicle and not reaching eye, and metaventrite shorter than abdominal ventrite 1 . The new genus belongs to the subtribe Tylodina based on the metaventrite shorter than abdominal ventrite 3 , abdominal process as wide as metacoxa, metepisternum narrow, and elytra with reduced humeri.

Baltacalles triumurbium sp. nov. urn:lsid:zoobank.org:act:064999A3-EE1E-4A7B-9E5F2F77BE3FB31C; Figs. 1-2

\section{Etymology}

Specific epithet is formed after the Latin phrase tres urbs in the genitive case and is the toponym referring to Trójmiasto ("Tricity") - a metropolitan area consisting of three cities (Gdańsk, Sopot and Gdynia) on the coast of the Gdańsk Bay.

\section{Type material}

Holotype: 6274 (ex. coll. Jonas Damzen JDC 8115) (MAIG); adult, sex unknown. Complete beetle is included in elongate, transparent amber piece, with dimensions of $34 \times 9 \times 7 \mathrm{~mm}$. Syninclusions: one specimen of Nematocera (Diptera), few stellate Fagaceae trichomes, and many small gas vesicles.

\section{Type stratum}

Baltic amber from Eocene amber-bearing Blue Earth layers, mostly Bartonian age is interpreted for the extinct central European resin-producing forests according to Bukejs et al. (2019).

\section{Type locality}

Baltic Sea coast, Yantarny settlement (formerly Palmnicken), Sambia (Samland) Peninsula, the Kaliningrad Region, Russia. 


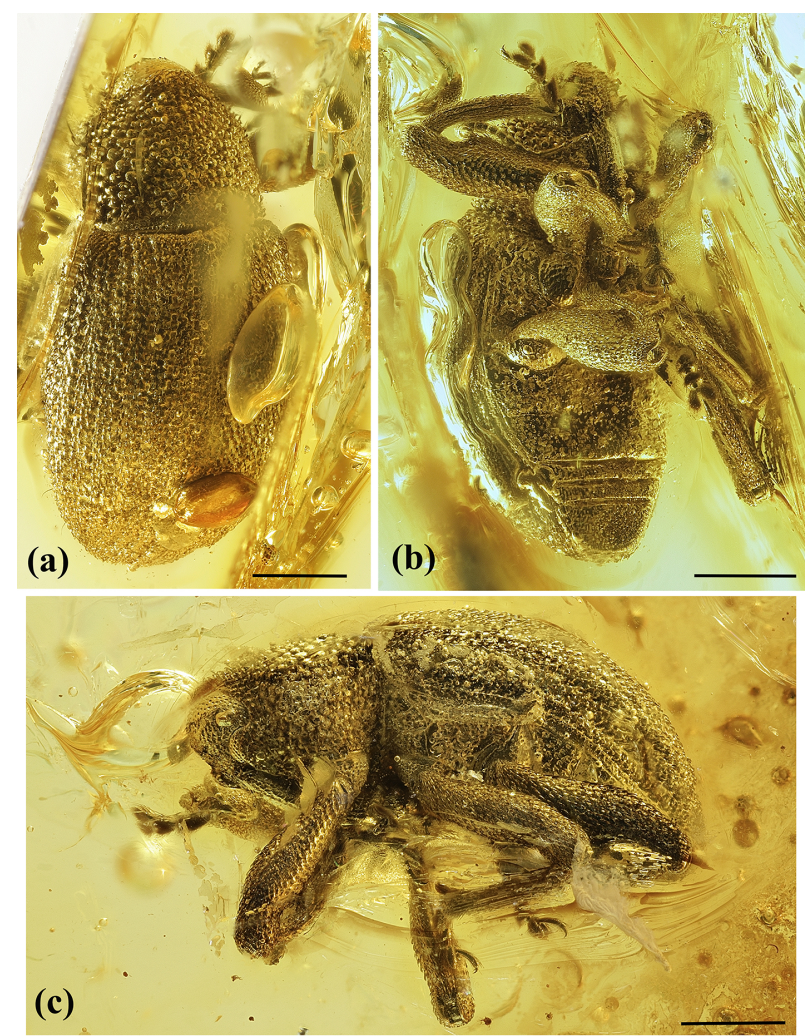

Figure 1. Baltacalles triumurbium gen. et sp. nov., holotype, 6274 (MAIG): (a) habitus, dorsal view; (b) habitus, ventrolateral view; (c) habitus, left lateral view. Scale bars $=1 \mathrm{~mm}$.

\section{Description}

Measurements: body length (without rostrum) $5.2 \mathrm{~mm}$, body maximum width about $2.8 \mathrm{~mm}$, rostrum length about $1.7 \mathrm{~mm}$; pronotum length $1.3 \mathrm{~mm}$, pronotum maximum width $1.85 \mathrm{~mm}$; elytra length $3.8 \mathrm{~mm}$, elytra maximum width about $2.8 \mathrm{~mm}$.

Body elongated oval, moderately convex; integument unicolorous, dark brown (as preserved).

Pubescence: dorsum moderately densely covered with short, elongate, almost recumbent brown scales; elytra additionally with two moderately long, erect setae latero-apically; anterolateral parts of prosternum additionally with long, curved seta; head (anteriorly) and rostrum (basally) with sparse, short, stout setae, rostrum with few long, erect setae apically; venter and legs moderately densely covered with short, stout setae, abdominal ventrites 3-5 with slightly denser and finer setation.

Head densely covered with small punctation, distance between punctures less than the diameter of one puncture, interspaces slightly convex, with secondary micropunctation. Rostrum long, $1.3 \times$ as long as pronotum, about $4.3 \times$ as long as wide at apex, $2.9 \times$ as long as wide at base and medially; distinctly narrower than head capsule; with fine, sparse
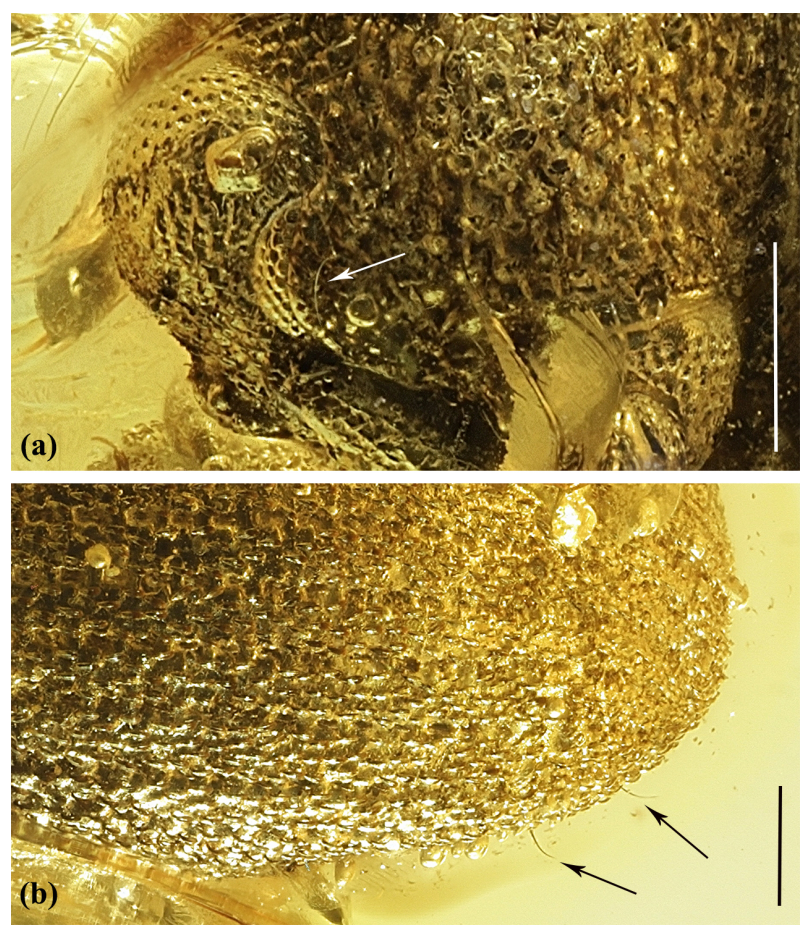

Figure 2. Baltacalles triumurbium gen. et sp. nov., holotype, 6274 (MAIG): (a) forebody, lateral view; (b) details of left elytron, dorsal view. The arrows indicate long setae. Scale bars $=0.5 \mathrm{~mm}$.

punctation and microreticulation, and apparently with shiny, glabrous longitudinal area dorsally; antennal scrobes lateroventral. Forehead narrow, almost flat. Vertex slightly convex. Compound eyes large, hemispherical, convex, with large facets; partially covered by anterolateral sides of prosternum. Antennae geniculate, with 11 antennomeres, clavate, moderately long, sparsely covered with fine setae, with distinct 3segmented club; scape long, about as long as antennomeres 2-3 combined, slightly dilated apically; antennomeres $2-3$ equal in size and shape, strongly elongate, about $4.3 \times$ as long as wide; antennomeres 4-6 slightly elongate, subcylindrical; antennomeres 7-8 distinctly dilated apically, about as wide as long; antennal club compact, spindle-shaped, rather short; antennomeres 9-10 transverse, $1.2 \times$ as wide as long; antennomere 11 conical with pointed apex, about $0.8 \times$ as wide as long; relative length ratios of antennomeres $1-11$ equal to $\sim 32-17-17-9-9-6-6-6-8-8-11$.

Pronotum nearly bell-shaped, widest in basal one-third, transverse, $1.4 \times$ as wide as long, narrower than anterior elytral margin, with weak constriction at anterior margin, distinctly narrowed anteriad and slightly narrowed posteriad, disk slightly convex; densely covered with large punctation, distance between punctures less than the diameter of one puncture, some discal punctures almost contiguous, interspaces slightly convex, with secondary micropunctation; lateral margins evenly slightly convex, anterior margin slightly convex, posterior margin almost straight. 


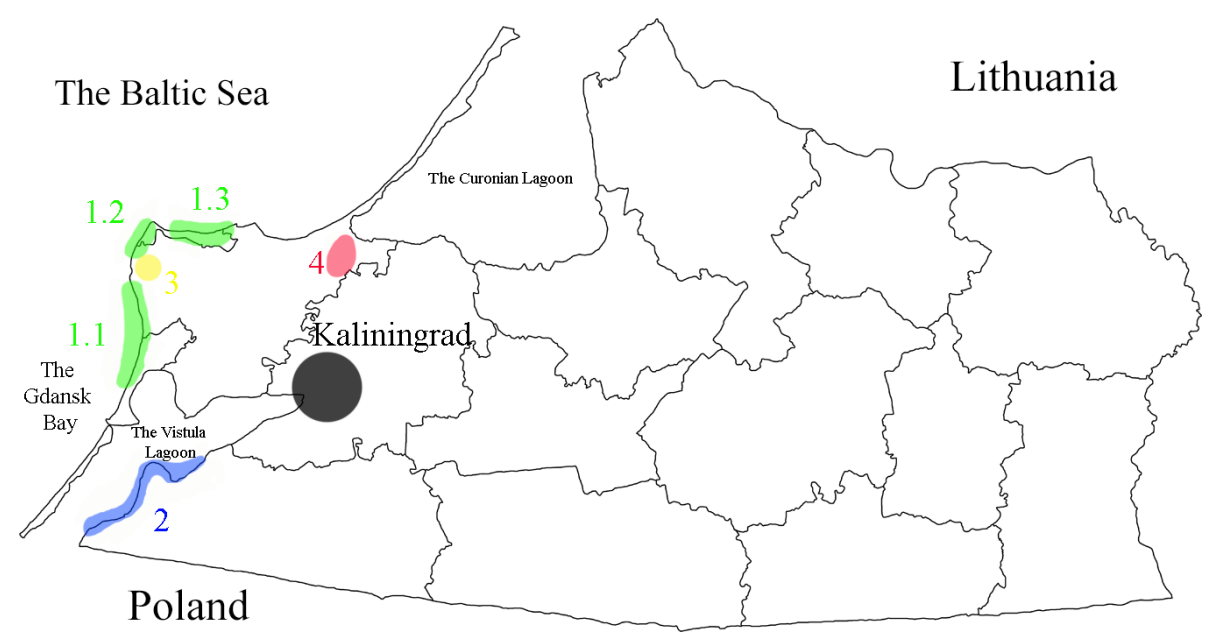

Figure 3. Map of the administrative subdivision of the Kaliningrad Region showing the main regional Baltic amber localities.

Scutellum minute, distinct, roundish, apparently impunctate.

Elytra elongate, about $1.4 \times$ as long as maximum wide, $2.9 \times$ as long as pronotum, subparallel-sided, punctatestriate, humeral calli weakly convex, basal margin slightly concave. Elytral punctures small and dense (discal punctation larger and denser), arranged in regular rows, distance between punctures in rows equal to $0.7-1.5 \times$ diameter of puncture; intervals distinctly convex, distance between rows about 2-2.5× diameter of puncture; sutural stria lacking.

Prohypomera convex in anterior portion, densely covered with moderately large punctures, distance between punctures smaller than diameter of one puncture, interspaces convex. Anterolateral parts of prosternum convex, projecting anteriad. Metepisternum narrow, with moderately small and sparse punctures. Metaventrite with large, dense punctures, interspaces convex; slightly narrower (medially) than abdominal ventrite 3 .

Abdomen: with five visible ventrites oriented in one plane; abdominal punctation fine to small: ventrites 1-2 with small, sparse punctures laterally and with fine, sparse punctures medially, ventrites 3-4 with fine, moderately dense punctures, ventrite 5 with fine and denser punctures; abdominal suture between ventrites 1-2 fine, visible laterally only, obsolete medially, abdominal sutures between ventrites $2-5$ distinct throughout its length, sharp and deep; intercoxal process of ventrite 1 wide, apparently slightly wider than transverse diameter of metacoxa; ventrites 1-2 with shallow impression medially; ventrite 5 with widely rounded apex; relative length ratios of abdominal ventrites 1-5 equal to 24-16-7-716 (medially).

Legs long, slender, densely covered with small punctures. Procoxae subconical, located in posterior portion of prothorax; mesocoxae hemispherical, separated by nearly $1 \times$ diameter of mesocoxa; metacoxae widely oval, transverse, about $2.3 \times$ as wide as long, widely separated by about $1 \times$ transverse diameter of metacoxa. Femora elongate, clavate, swollen in apical portion, with ventral denticle, slightly longer than femora. Tibiae moderately robust, slightly flattened, slightly curved inwards, with large uncus, and two groups of setae; protibiae distally without mouth groove and row of dense erect setae (grooming device); mesotibiae without denticle in middle of exterior margin. Tarsi moderately long (protarsus $0.6 \times$ as long as protibia), setaceous, pelma well-developed; tarsomere 1 elongate, dilated apically, 1.5$1.6 \times$ as long as tarsomeres 2 , tarsomere 2 transverse, trapezoidal, tarsomere 3 deeply bilobed, transverse, ultimate tarsomere elongate, projecting from tarsomere 3 to about half of its length. Tarsal claws small, free, simple.

\section{Discussion}

\section{Records of fossil Molytinae}

The oldest records of the subfamily Molytinae based on the reliable representatives are known from the Paleocene (Piton, 1940; Legalov, 2010). Some isolated elytra possibly belonging to Molytinae are described from Maastrichtian (Legalov, 2015). The tribes Acicnemidini, Pissodini, Magdalinini, Molytini, Plinthini, Mecysolobini and Aedemonini are recorded from Baltic amber (Legalov, 2020). The tribe Cryptorhynchini, formerly regarded as a separate subfamily (Alonso-Zarazaga and Lyal, 1999), is here considered as a part of the subfamily Molytinae (Lyal, 2014). The tribe consists of two subtribes: Cryptorhynchina and Tylodina (Legalov, 2018). The first records are from the early Eocene Oise amber (Legalov et al., 2019), the early Eocene of London Clay (Britton, 1960) and the early-middle Eocene of Green River (Scudder, 1876). One species is described from the middle Eocene of Geisel valley (Haupt, 1950). The rich Cryptorhynchini fauna is known from the Miocene Dominican amber (Poinar and Legalov, 2014). Only one species of 


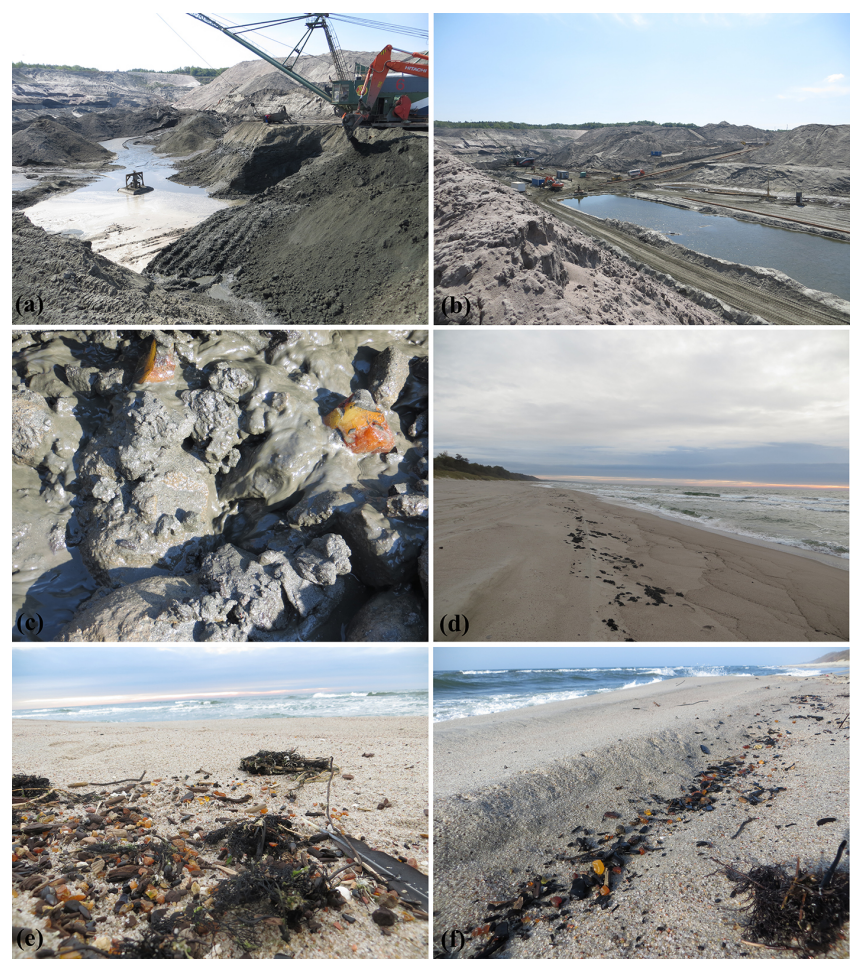

Figure 4. The main local sources of amber in the Kaliningrad Region: (a-c) the industrial open pit mining "Primorskoje" in Yantarny ("Palmnicken"), the Blaue Erde deposits (photographed 20 May 2019); (d-f) the Baltic Sea coasts southwards of the Yantarny settlement ("Nodems"), supralittoral zone after west wind (photographed 27 February 2019).

the subtribe Cryptorhynchina (Zherikhin, 1971) is descried, and one representative of the subtribe Tylodina is recorded (Klebs, 1910) from late Eocene Baltic amber.

\section{Notes concerning local differences of Baltic amber in the Kaliningrad Region}

Amber is a significant source of information about terrestrial forest and woodland ecosystems. The historically beststudied Baltic amber connected with Eocene of northeastern Europe is among the biotically richest amber deposits in the world. At the present time, this amber is found mainly along coastlines of the Baltic on beaches or in different geological Tertiary and Quaternary layers, but the source stratum, the Paleogene Blaue Erde (Blue Earth), is particularly productive in the west of the Samland (Sambia) Peninsula. The ages of succinite-bearing horizons can differ by at least $7 \mathrm{Myr}$ according to stratigraphy (Bukejs et al., 2019). Baltic amber of the Kaliningrad Region is not uniform in regional view and originates from several regionally different localities (with distance of $\pm 100 \mathrm{~km}$ ), comes from different stratigraphic layers (from the Eocene source stratum and stratum above) and is obtained by the different methods. The conventional formal data the Samland/Sambia Peninsula, Baltic amber,

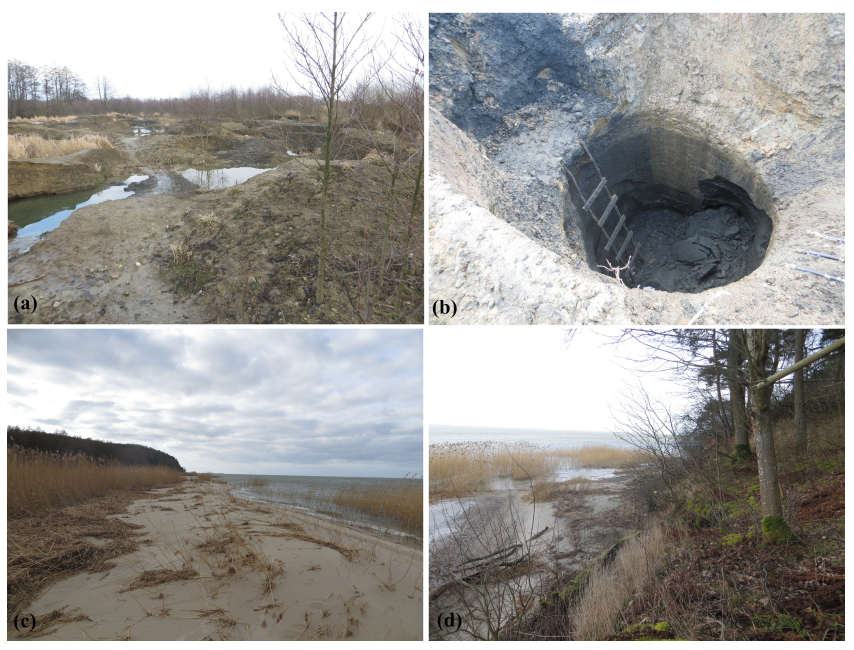

Figure 5. The main local sources of amber in the Kaliningrad Region: (a-b) the illegal dig holes westwards of the Sosnovka settlement ("Steinitten") (photographed 15 February 2020); (cd) the coast of the Vistula Lagoon ("Korschenruh") (photographed 17 February 2020).

Upper Eocene used in the majority of paleontological publications as type locality and type horizon for Baltic amber inclusions are generally reasonable and more or less correct. However, they could (and should) be provided more exactly (if possible) according to local view. Such information, unfortunately available in museums or by dealers in rare cases only, could be significant for the understanding of processes during Baltic amber deposit formation, the possible gradual faunal changes in the forest ecosystems of the Fennoscandia, and possible age-differing amber-bearing stratigraphy.

The main local sources of the Baltic amber in the Kaliningrad Region (Fig. 3) can be tentatively listed as the following (according to Andrée (1951) and the authors own data and observations):

1. the surf zone of the Baltic Sea along the coastline from the Baltic Spit to the Curonian Spit, including at least three main sampling sectors (the German names of localities are provided in parentheses for the purposes of tradition and absence of the modern conventional geographic names):

1.1 the coasts southwards of the Yantarny settlement ("Nodems") (Fig. 4d-f);

1.2 the coasts between the Yantarny settlement and Donskoe ("Kraxtepellen-Groß Dirschkeim");

1.3 the northern Sambia coasts from Filino to Svetlogorsk ("Klein Kuhren-Rauschen");

2. the coastal area of the Vistula Lagoon from Mamonovo to Ladygino ("Heiligenbeil-Korschenruh") (Fig. 5c-d);

3. the official industrial open pit mining "Primorskoje" in Yantarny ("Palmnicken") (Fig. 4a-c); 
4. the illegal dig holes westwards and southwards of the Sosnovka settlement ("Steinitten") (Fig. 5a-b).

The composition, history of formation and the current stratigraphic origin of these sampling localities is different. However, all the sites could be globally treated as Baltic amber from the Sambia Peninsula coming from the Eocene Blaue Erde.

Baltic amber evidently has terrigenous origin: the glauconitic Blaue Erde containing the succinite (as it is in localities 3 and 4 at the present time) is formed in the shallow marine waters and is at least the secondary deposit for the amber formed in Eocene forests. The ambers from the localities 1 (partially) and 2 are additionally re-deposited from the Eocene layers (and thereby are at least twice re-deposited from a primary terrestrial horizon) and comprise at least the tertiary accumulations of Tertiary amber.

The amber from surf zones of the Baltic Sea (group 1) could be transported by the sea currents and winds from place to place and is especially intermixed and comes from different coastal layers including the underwater outcrops of the Blaue Erde of the Sambia Peninsula and all the overlying strata. The amber from the eastern coasts of Vistula Lagoon (group 2) comes from the Quaternary accumulations of the post-glacial origin. The amber from the industrial mine eastwards of the Yantarny settlement is situated in the original and intact Upper Eocene horizon (the most productive upper layers at a depth of no less than 10-15 m are only excavated). The amber of illegal excavations in the northeast of the Zelenogradsk district (group 4) belongs to the secondary deposit formed after re-deposition in the Pleistocene and is situated in the layers of the transported by the glaciation upper horizon of the Blaue Erde lying about $2 \mathrm{~m}$ deep. All these local differences could cause or explain the differences in the preservation state of inclusions, the amber size and, consequently, the possible maximal size of inclusions, and, perhaps, a variation in faunal composition. The material coming from localities 1 and 2 is biased against large insects because of the higher possibility of breakage of the layered inclusion-bearing ambers in the surf zone. It is also the most oxidized (especially in locality 2) because of the present-day atmospheric impact.

The importance of the possible exact labeling of the material under study is evident, and it is important for a more complete understanding of several questions in future.

Data availability. No data sets were used in this article.

Author contributions. $\mathrm{AB}$ and $\mathrm{AAL}$ designed the study. AB prepared new species descriptions and plates. AAL prepared the new genus description and performed new taxa systematic placement. VIA suggested ideas for discussion, drew the map and took the photos used in Figs. 4 and 5. All authors drafted the manuscript and contributed to the writing and discussion.
Competing interests. The authors declare that they have no conflict of interest.

Acknowledgements. The authors are sincerely grateful to Elżbieta Sontag (Museum of Amber Inclusions, University of Gdańsk, Poland) and to Jonas Damzen (Vilnius, Lithuania) for informing us about the interesting specimen, assistance during our amber research and permission to use photographs of the holotype. We thank the two anonymous reviewers for valuable suggestions that improved the manuscript. The study of VIA was done with the support of the state assignment of IO RAS (no. 0149-2019-0013).

Financial support. This research of VIA has been supported by the IO RAS (grant no. 0149-2019-0013).

Review statement. This paper was edited by Rene Hoffmann and reviewed by two anonymous referees.

\section{References}

Alonso-Zarazaga, M. A. and Lyal, C. H. C.: A world catalogue of families and genera of Curculionoidea (Insecta: Coleoptera), Entomopraxis, Barcelona, Spain, 315 pp., 1999.

Andrée, K.: Der Bernstein, Das Bernsteinland und sein Leben. Stuttgart, Kosmos, Francksche Verhandlung, 95 pp., 1951.

Britton, E. B.: Beetles from the London Clay (Eocene) of Bognor Regis, Sussex, Bull. Br. Mus. (Nat. Hist.), Geologica, 4, 27-50, 1960.

Bukejs, A., Alekseev, V. I., and Pollock, D. A.: Waidelotinae, a new subfamily of Pyrochroidae (Coleoptera: Tenebrionoidea) from Baltic amber of the Sambian peninsula and the interpretation of Sambian amber stratigraphy, age and location, Zootaxa, 4664, 261-273, https://doi.org/10.11646/zootaxa.4664.2.8, 2019.

Haupt, H.: Die Käfer (Coleoptera) aus der Eozänen Braunkohle des Geiseltales, Geologica, 6, 1-168, 1950.

Klebs, R: Über Bernsteinschlüsse im allgemein und die Coleopteren meiner Bernsteinsammlung, Schr. Phys.-Ökonom. Gesellsch. Königsberg Pr., 51, 217-242, 1910.

Lacordaire, T.: Histoire Naturelle des Insectes. Genera des Coléoptères ou exposé méthodique et critique de tous les genres proposés jusqu 'ici dans cet ordre d'insectes, 7. Paris, Roret, 620 pp., 1865.

Latreille, P. A.: Histoire Naturelle, Générale et Particulière, des Crustacés et des Insectes. Ouvrage faisant suite aux Oeuvres de Leclercq de Buffon, et partie du Cours complet d'Histoire naturelle rédigé par C. S. Sonnini, membre de plusieurs Sociétés Savantes, 3. Paris, Dufart, 467 pp., 1802.

Lawrence, J. F., Beutel, R. G., Leschen, R. A. B., and Ślipiński, S. A.: Glossary of Morphological Terms, chap. 2, in: Handbook of Zoology, Arthropoda: Insecta, Tb. 40, Coleoptera (Beetles), Vol. 2, Morphology and Systematics (Elateroidea, Bostrichformia, Cucujiformia partim), Berlin, New York, Walterde Gruyter, 920,2010 
Legalov, A. A.: Checklist of Mesozoic Curculionoidea (Coleoptera) with description of new taxa, Baltic, J. Coleopterol., 10, 71-101, 2010.

Legalov, A. A.: Fossil weevils (Coleoptera, Obrienioidea, Curculionoidea) from Mesozoic and Cainozoic, Paleontol. J., 49, 1442-1513. https://doi.org/10.1134/S0031030115130067, 2015.

Legalov, A. A.: Annotated key to weevils of the world, Part 2: Subfamily Molytinae (Coleoptera, Curculionidae), Ukrainian, J. Ecol., 8, 340-350, 2018.

Legalov, A. A.: A review of the Curculionoidea (Coleoptera) from European Eocene ambers, Geosciences, 10, 1-74. https://doi.org/10.3390/geosciences10010016, 2020.

Legalov, A. A., Kirejtshuk, A. G., and Nel, A.: New weevils (Coleoptera, Curculionoidea) from the earlymost Eocene Oise amber, Paleontol. J., 53, 729-751, https://doi.org/10.1134/S0031030119070049, 2019.

Lyal, C. Y. C.: 3.7.7. Molytinae Schoenherr, 1823, in: Handbook of Zoology, Arthropoda: Insecta, Tb. 40, Coleoptera (Beetles), Vol. 3, Morphology and Systematics (Phytophaga), edited by: Leschen, R. A. B. and Beutel, R. G., De Gruyter, Berlin/Boston, 529-569, 2014.
Piton, L.: Paléontologie du Gisement Eocène de Menat (Puyde-Dôme), Flore et Faune, Mém. Soc. d'histoire naturelle d'Auvergne, Clermont-Ferrand, 1, 1-303, 1940.

Poinar Jr., G. and Legalov, A. A.: New Cryptorhynchinae (Coleoptera: Curculionidae) in Dominican amber, Hist. Biol., 26 502-534. https://doi.org/10.1080/08912963.2013.797971, 2014.

Schoenherr, C. J.: Curculionides (Tabulae synopticae Familiae Curculionidum), Isis von Oken, 1132-1146, 1823.

Schoenherr, C. J.: Continuatio Tabulae synopticae Familiae Curculionidum, Isis von Oken, 581-588, 1825.

Scudder, S. H.: Fossil Coleoptera from the Rocky Mountain Tertiaries, Bull. US Geol. Geogr. Surv. Territ., 2, 77-87, 1876.

Zherikhin, V. V.: O dolgonosikach (Insecta, Coleoptera) Baltiyskogo Jantarja [On the weevils (Insecta, Coleoptera) from the Baltic Amber], Trudy Palaeontologicheskogo Instituta, 130, 197-209, 1971. 